\title{
Association between interleukin $1 \beta$ and interleukin 10 concentrations: a cross-sectional study in young adolescents in Taiwan
}

\author{
Jung-Su Chang ${ }^{1}$, Chun-Chao Chang ${ }^{2,3}$, Eve Yiwen Chien ${ }^{1}$, Sean S-H Lin ${ }^{1}$, Tsai Cheng-Shiuan ${ }^{4}$, Chyi-Huey Bai ${ }^{5}$
} and Kuo-Ching Chao ${ }^{2,3^{*}}$

\begin{abstract}
Background: In adults, low circulating interleukin 10 (IL10) has been associated with obesity and type 2 diabetes. However, studies investigating IL10 in overweight and obese children have yielded conflicting results. The aim of this study was to investigate factors associated with serum IL10 concentration in young Chinese adolescents.

Methods: Young adolescents ( $n=325)$ ages $13.33 \pm 1.10$ years were recruited into the cross-sectional study from 2010 to 2011. Parameters of obesity, individual components of MetS, iron status and serum IL10 were evaluated.

Results: Compared with their normal weight counterparts, overweight adolescents had lower serum IL10 but higher TNFa, nitric oxide (NO) and IL1 $\beta$ concentrations (all $p<0.05$ ). Obese adolescents had increased IL1 $\beta$ but decreased hepcidin concentration compared with normal weight ( $p<0.01$ and $p<0.05$; respectively). A strong inverse relationship ( $p<0.0001$ ) was found between IL10 and pro-inflammatory cytokines (TNFa and IL1 $\beta$ ). Multivariate linear regression analysis showed serum IL $1 \beta$ was significantly correlated with IL 10 ( $\beta=-0.156$, $p<0.0001)$. When overweight and obese adolescents were assessed separately from normal weight, only IL $1 \beta$ was inversely associated with serum IL10 $(\beta=-0.231, p=0.0009)$. The association between IL10 and IL1 $\beta$ was weaker in adolescents with normal weight ( $\beta=-0.157, p=0.0002$ ), after adjusting for gender, TNFa, IFNY and NO.

Conclusions: Our study confirmed that low IL10 concentration is associated with overweight and obesity in young adolescents. We also demonstrated for the first time that pro-inflammatory cytokine IL $1 \beta$ is independently associated with IL10. A decline in IL10 concentration in overweight and obese adolescents may further contribute to the IL1 $\beta$-mediated inflammatory environment associated with obesity.
\end{abstract}

Keywords: IL10, IL1 $\beta$, Overweight and obese adolescents, Taiwan

\section{Background}

Interleukin 10 (IL10) plays a central role in regulating immune response and limiting inflammation. IL10 suppresses inflammation through various mechanisms including inhibition of the synthesis of pro-inflammatory cytokines such as IL12 and TNF $\alpha$ via suppression of p65 NF-kB and c-rel activity in macrophages [1]. IL-10 is also important in down-regulation of the release of reactive oxygen species and nitrogen intermediates;

\footnotetext{
*Correspondence: chin3064@gmail.com

${ }^{2}$ Division of Gastroenterology and Hepatology, Department of Internal Medicine, Taipei Medical University Hospital, Taipei, Taiwan R.O.C

${ }^{3}$ Department of Internal Medicine, School of Medicine, College of medicine,

Taipei Medical University, 110, Taipei, Taiwan R.O.C

Full list of author information is available at the end of the article
}

regulation of antigen presentation capacity and immune tolerance [2]; and suppression of proliferative and cytotoxic $\mathrm{T}$ cell responses [3].

There is growing evidence linking IL10 to obesity [4], metabolic syndrome (MetS) and cardiovascular disease [5]. In adults, low circulating IL10 has been associated with obesity [6], cardiovascular disease [7-9] and type 2 diabetes [5,10-12]. Clinical significance of circulating IL10 concentrations have been demonstrated in acute coronary syndrome $[8,9]$ and insulin resistance [5,10-12]. The balance of pro-and anti-inflammatory cytokines is an important determinant of atherosclerotic plaque instability. IL10 expression has been found within human atherosclerotic plaques [13]. Smith et al. studied 95

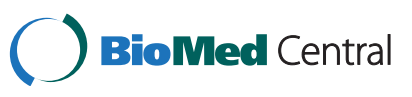


patients with angina and related coronary artery disease and observed significantly lower serum IL10 concentrations in patients with unstable angina compared with those with stable angina [9]. Heeeschen et al. investigated the prognostic impact of $\mathrm{C}$-reactive protein (CRP) and IL10 in patients with acute coronary syndrome and reported elevated IL10 concentrations were strongly associated with prognosis of acute coronary syndromes [8]. The predictive value of IL10 was independent of myocardial necrosis but significantly interacted with CRP concentration, suggesting the importance of the balance between pro-inflammatory and antiinflammatory cytokines as a major determinant of patient's outcome in acute coronary syndromes [8].

IL10 also plays a protective role against the development of insulin resistance. Plasma IL10 concentrations were positively correlated with insulin sensitivity in young healthy adults $(\mathrm{r}=0.37, \mathrm{p}=0.00023)$ [11]. Forte et al. performed the grade-of-membership analysis in 490 type 2 diabetic and 349 control subjects of Italian Caucasians [14]. The authors reported $74.4 \%$ of subjects negative for IL-10 -824 $\mathrm{T}$ allele were diabetic patients characterized by vascular damages, suggesting that IL10 $-597 \mathrm{~A} /-824 \mathrm{~T} /-1087 \mathrm{~A}$ negative subjects are more prone to the major type 2 diabetic vascular damages [14].

Studies investigating IL10 in children and young adolescents with obesity have yielded conflicting results [15-18]. According to a study by Gozal and colleagues, obese children with obstructive sleep apnea had low plasma IL10 concentration [17]. In a study including 70 severely obese and 30 normal weight children aged 11.46 \pm 3.42 years old, Calcaterra and colleagues reported that serum IL10 concentrations were higher in severely obese children compared to normal weight [16]. Tam et al. reported no differences in IL10 concentration between normal and overweight children at 8 years old; however, at 15 years old, serum IL10 was elevated in overweight and obese girls when compared to normal weight girls of same age [18]. These data suggest that effects of obesity on IL10 serum concentration vary with age, sex and obesity-related complications. Additionally, the possible association between IL10 and iron status has also been highlighted in some studies. For instance, patients receiving high doses of IL10 developed hyperferritinemia [19] whereas iron supplementation in IL10- knock out mouse increased pro-inflammatory cytokine production in high iron diet group compared with chow diet [20].

In adults, IL10 plays a protective role against the development of obesity-related declines in health. However, the effect of obesity on IL10 concentration in children is not clear. We therefore measured IL10 concentration and investigated the factors associated with IL10 homeostasis in young adolescents. The variables analyzed included: 1) anthropometry; 2) individual components of metabolic syndrome; 3) proinflammatory and oxidative stress markers; and 4) iron parameters.

\section{Methods}

\section{Study design and participants}

This cross-sectional study involved young adolescents from 2 junior high schools located in Taipei and New Taipei City, Taiwan. From September 2010 to November 2011, 340 subjects (ages $13.33 \pm 1.10$ years, 182 boys and 158 girls) were enrolled in the study. Exclusion criteria were as follows: individuals with missing data for clinical biochemistry and anthropometry $(n=14)$ and individuals with abnormal serum ferritin concentration $(>500 \mathrm{ng} / \mathrm{ml})(\mathrm{n}=1)$. A total of 325 adolescents were included in the analysis. Informed parental consent was obtained for enrollment into the study. The study was approved by the Research Ethics Committee of Taipei Medical University (201204011).

\section{Data collection}

Data was collected from the subjects by the same medical staff from the Taipei Medical University Hospital using the same methods and tools. Children were advised not to drink or eat after midnight or exercise 24 hours prior to data collection. On the morning of the study, fasted children who were free of medical conditions were admitted to the school-based health center. Body weight, height, waist circumference, $\%$ body fat and blood pressure measurements were obtained by standard methods as described elsewhere [21]. Waist circumference was measured at the midpoint between the lower edge of the rib cage and the top of the iliac crest [22]. Age-sex specific cut off point for body mass index (BMI) was used to define overweight and obesity in adolescent according to guidelines of the Department of Health in Taiwan $[23,24]$. BMI was calculated as mass $(\mathrm{Kg}) /[$ height $(\mathrm{m})]^{2}$. Subjects with BMI greater than 85 th percentile of age-sex-specific value were grouped as overweight while those with BMI greater than 95th percentile were classified as obese. Percentage of body fat was estimated by bioelectrical impedance method (Omron Body Fat Analyzer HBF-306).

Metabolic syndrome (MetS) was defined based on the modified International Diabetes Federation (IDF) criteria for $10-<16$ years old children and adolescents [25]. Individuals with the presence of $\geqq 3$ criteria listed below were classified as MetS: (1) waist circumference: $\geq 90 \mathrm{~cm}$ for boys and $\geq 80 \mathrm{~cm}$ for girls; (2) triglyceride (TG): $\geq 150 \mathrm{mg} / \mathrm{dL}$; (3) fasting plasma glucose (FPG): $\geq 100 \mathrm{mg} /$ dL; (4) high density lipoprotein cholesterol (HDL): $<40 \mathrm{mg} / \mathrm{dL}$ for boys and $<50 \mathrm{mg} / \mathrm{dL}$ for girls; and (5) systolic blood pressure $(\mathrm{SBP}) \geq 130 \mathrm{mmHg}$ or diastolic blood pressure $(\mathrm{DBP}) \geq 85 \mathrm{mmHg}$. 


\section{Blood biochemistry examination}

Fasting blood samples were collected in vacuum tubes containing either EDTA or lithium heparin. All blood samples were separated into red blood cells and serum and stored at $-80^{\circ} \mathrm{C}$ until analysis. Total cholesterol (TC), LDL, HDL and TG were determined by an autoanalyzer (Hitachi 737, USA). Fasting plasma glucose concentration was detected using a glucose oxidase method (YSI 203 glucose analyzer, Yellow Springs Instruments, Yellow Springs, OH). Serum ferritin was measured using a commercially available electrochemiluminescence immunoassay and was quantitated by the Roche Modular P800. Serum iron and total iron binding capacity (TIBC) were measured by ferrozine-based colorimetric method. Percentage transferrin saturation (\% TS) was calculated by serum iron/TIBC $\times 100 \%$. Serum hepcidin was assessed by an enzyme-linked immunosorbent assay (DRG International Inc; Marburg). The assay dynamic range is between $2.5 \mathrm{ng} / \mathrm{ml}-140 \mathrm{ng} / \mathrm{ml}$. Definitions of abnormal biochemistry blood lipid, glucose profiles [26] and iron status [27] are described elsewhere. Cytokines concentrations (IL1 $\beta$, TNF $\alpha$, IL10, IFN $\gamma$ ) were determined by Enzyme-Linked Immunosorbent Assay kit (Procarta Cytokine Assay Kit; Affymetrix, Inc., USA) according to the manufacturer's instructions. Nitric oxide (NO) concentration in the serum was determined by Griess reagent system. The coefficients of variation (CV) for normal weight and overweight/obese adolescents were: IL1 $\beta$ (36.1\% v.s. 36.4\%), TNF $\alpha$ ( $41.2 \%$ v.s. $48.9 \%)$, IL10 (26.9\% v.s. $28.9 \%)$, IFN $\gamma$ (36.4\% v.s $30.8 \%)$ and $\mathrm{NO}$ (89.5\% v.s. $86.3 \%)$.

\section{Statistical analyses}

Statistical analyses were performed using the Statistical Analysis Systems software (SAS version 9.22; SAS Institute, Inc). Normally distributed data were presented as means \pm standard error of mean (SEM). Differences between groups were analyzed by the unpaired t-test. Chisquare or Fisher's Exact Test were used for comparison of proportions. Variables not normally distributed were natural log-transformed to achieve a normal distribution but untransformed values were used for reporting results. The association between serum IL10 concentration and clinical and blood biochemistry parameters were assessed using Pearson's correlation coefficient. A multivariate linear regression model was used to examine the relationship between the dependent variable (serum IL10) and potential variables. The $P$ value was $p<0.05$ except for the analysis in Table 1 where a value of $\mathrm{p}<0.0023$ was used based on Bonferroni correction for multi-comparisons.

\section{Results}

Participant characteristics

A total of 325 children were entered in this study. 231 children were classified as normal body weight while 94 children were diagnosed as overweight or obese. Table 2 shows clinical and biochemical characteristics of study subjects according to nutritional status. The prevalence of overweight was $13.5 \%$ (19.67\% for boys and $18.30 \%$ for girls) and obesity was $15.4 \%$ (23.77\% for boys and $19.26 \%$ for girls). Children with high triglyceride concentration were $5.5 \%$ (4.0\% for boys and $7.3 \%$ for girls) while $21.5 \%$ had low HDL (7.43\% for boys and 38\% for girls). About $12 \%$ of children had elevated fasting glucose concentration ( $15.4 \%$ for boys and $8 \%$ for girls). Only one male adolescent had fasting plasma glucose concentration $>126 \mathrm{mg} / \mathrm{dl}$. Five girls were diagnosed with MetS, which was $1.58 \%$ of all the subjects.

\section{Altered cytokine profiles in overweight and obese adolescents}

Compared with their normal weight counterparts, overweight adolescents had lower serum IL10 but higher TNF $\alpha, N O$ and IL1 $\beta$ concentrations (all $\mathrm{p}<0.05$; Table 2). Obese adolescents had increased IL1 $\beta$ but decreased hepcidin concentration compared with the respective concentration in normal weight adolescents $(\mathrm{p}<0.01$ and $\mathrm{p}<0.05$; respectively). There were no differences in circulating IFN $\gamma$ between the two groups. No sex differences were found in cytokine profiles except IL1 $\beta$. Overweight/obese boys and girls had significantly higher serum IL1 $\beta$ concentration compared with respective normal weight boys and girls (boys: $1.19 \pm 0.05$ v.s. $1.0 \pm 0.03 \mathrm{pg} / \mathrm{ml} ; \quad \mathrm{p}<0.05$; girls: $1.17 \pm 0.06$ v.s. 0.94 $\pm 0.03 \mathrm{pg} / \mathrm{ml} ; \mathrm{p}<0.01$ ) (data not shown).

We grouped the individuals according to the IL10 concentration to investigate the potential confounding variables that are associated with IL10 concentration. The clinical characteristics of the study adolescents in relation to tertile groups of IL10 are shown in Table 1. An inverse correlation was found between BMI and IL10 tertiles but it did not reach statistical significance (Table 1). Furthermore, no correlation was found between IL10 terriles and the individual components of metabolic syndrome. IL10 tertiles were positively correlated with transferrin saturation $(\mathrm{p}=0.0167)$ and serum hepcidin $(\mathrm{p}<0.0001)$ but inversely correlated with serum total iron binding capacity (TIBC) $(\mathrm{p}=0.011)$. Proinflammatory cytokines such as TNF $\alpha$, IL1 $\beta$ and NO were inversely correlated with IL10 tertiles (all $\mathrm{p}<0.0001)$.

\section{Significant correlation between pro-inflammatory cytokines and IL10 concentration}

We next performed correlation analysis to identify the possible variables that were associated with IL10. Pearson's correlations between log serum IL10 and selected laboratory parameters are shown in Table 3. After adjusting for gender, IL10 was inversely correlated with 
Table 1 Clinical and biochemical characteristics of young adolescents according to IL10 tertiles ( $n=325$, boys=175 and girls=150)

\begin{tabular}{|c|c|c|c|c|c|c|c|}
\hline Variables $^{\#}$ & $\mathrm{~T}^{*}$ & & $\mathrm{~T}^{*}$ & & $\mathrm{T3}^{*}$ & & P-trend \\
\hline BMI $\left(\mathrm{kg} / \mathrm{m}^{2}\right)$ & 20.97 & \pm 4.3 & $20.65 \pm$ & 4.3 & 19.99 & \pm 3.2 & 0.0740 \\
\hline Body fat (\%) & 22.64 & \pm 8.7 & $21.95 \pm$ & 7.6 & 20.78 & \pm 6.78 & 0.0818 \\
\hline Waist circumference (cm) & 71.21 & \pm 11.9 & $70.55 \pm$ & 10.8 & 69.16 & \pm 9.9 & 0.1788 \\
\hline Fasting glucose (mg/dL) & 90.99 & \pm 8.67 & $91.81 \pm$ & 6.07 & 92.25 & \pm 7.79 & 0.2240 \\
\hline Fasting serum insulin $(\mu \mathrm{l} \mathrm{U} / \mathrm{ml})$ & 16.95 & \pm 14.2 & $16.87 \pm$ & 10.3 & 17.22 & \pm 15.8 & 0.8848 \\
\hline HOMA-IR & 3.98 & \pm 4.0 & $3.88 \pm$ & 2.5 & 4.05 & \pm 4.2 & 0.8940 \\
\hline Sytolic BP (mmHg) & 110.89 & \pm 11.0 & $112.33 \pm$ & 8.9 & 110.75 & \pm 8.5 & 0.9094 \\
\hline Diastolic BP (mmHg) & 62.88 & \pm 8.2 & $63.80 \pm$ & 8.7 & 63.41 & \pm 7.7 & 0.6371 \\
\hline HDL cholesterol (mg/dL) & 54.06 & \pm 12.3 & $56.31 \pm$ & 13.4 & 56.59 & \pm 12.67 & 0.1481 \\
\hline LDL- cholesterol (mg/dL) & 89.44 & \pm 27.0 & $91.64 \pm$ & 21.2 & 90.73 & \pm 24.2 & 0.6998 \\
\hline Triglyceride ((mg/dL)) & 76.53 & \pm 35.6 & $70.85 \pm$ & 31.2 & 78.23 & \pm 49.6 & 0.7537 \\
\hline Total cholesterol (mg/dL) & 159.9 & \pm 30.2 & $159.63 \pm$ & 24.2 & 160.75 & \pm 30.1 & 0.8420 \\
\hline Serum iron (ug/dL) & 87 & \pm 35.8 & $86.52 \pm$ & 33.1 & 95.32 & \pm 36.0 & 0.0833 \\
\hline Serum TIBC (ug/dL) & 352.1 & \pm 44.6 & $348.56 \pm$ & 47.2 & 337.01 & \pm 37.2 & 0.0114 \\
\hline Serum ferritin (ng/ml) & 57.87 & \pm 36.1 & $55.22 \pm$ & 37.0 & 55.92 & \pm 32.0 & 0.6844 \\
\hline Transferrin Saturation (\%) & 25.17 & \pm 10.7 & $25.14 \pm$ & 9.6 & 28.63 & \pm 11.1 & 0.0167 \\
\hline Hepcidin $(\mathrm{ng} / \mathrm{ml})^{\S}$ & 422.46 & \pm 418.7 & $554.71 \pm$ & 446.7 & 698.92 & \pm 420.7 & $<0.0001$ \\
\hline TNFa $(\mathrm{pg} / \mathrm{ml})^{\S}$ & 24.56 & \pm 11.2 & $18.96 \pm$ & 7.3 & 18.81 & \pm 6.7 & $<0.0001$ \\
\hline IFNy (pg/ml) & 6.72 & \pm 1.7 & $6.34 \pm$ & 2.3 & 6.24 & \pm 2.5 & 0.1148 \\
\hline $\mathrm{NO}(\mathrm{UM})^{\S}$ & 9.31 & \pm 4.3 & $7.10 \pm$ & 4.2 & 6.69 & \pm 4.3 & $<0.0001$ \\
\hline $\operatorname{IL} 1 \beta(\mathrm{pg} / \mathrm{ml})^{\S}$ & 1.26 & \pm 0.4 & $1.00 \pm$ & 0.4 & 0.86 & \pm 0.2 & $<0.0001$ \\
\hline
\end{tabular}

*IL10 cut-off point: Tertile 1: $<8.03 \mathrm{pg} / \mathrm{ml}$, Tertile $2>=8.03 \mathrm{pg} / \mathrm{ml}<=10.6 \mathrm{pg} / \mathrm{ml}$, Tertile $3>10.6 \mathrm{pg} / \mathrm{ml}$.

"Data are presented as means \pm standard error of mean (SEM) and percent for continuous and categorical variables respectively.

${ }^{\S}$ Bonferroni correction $\mathrm{p}<0.0023$.

$\log$ serum TIBC $(r=-0.137 ; p=0.013)$ and positively correlated with $\log$-transferrin saturation $(r=0.131 ; p=0.018)$ and log-hepcidin $(\mathrm{r}=0.271 ; \mathrm{p}<0.0001)$. Furthermore, strong inverse correlations were found between IL10 and IL1 $\beta \quad(r=-0.328, \quad P<0.0001), \quad$ IL10 and TNF $\alpha$ $(r=-0.209, \quad P=0.0001), \quad$ IL10 and NO $(r=-0.28668$, $P<0.0001)$, and between IL10 and IFN $\gamma \quad(r=-0.139$, $P=0.012$ ) (Table 3). We next separated overweight and obese adolescents from normal weight. All cytokines investigated continued to have strong inverse correlations with IL10 in normal weight adolescents [IFNY $(r=-0.253)$, TNF $\alpha \quad(r=-0.1773), \quad$ IL1 $\beta \quad(r=-0.347)$, NO $(r=-0.311)$; all $\mathrm{p}<0.0001]$. However, only IL1 $\beta$ was significantly correlated with IL10 in overweight and obese adolescents $(r=-0.376, P<0.0001)$ (data not shown).

\section{IL1 $\beta$ Is independently correlated with IL10 concentration}

We next performed multiple linear regression analysis to predict variants that were independently associated with IL10 concentration. Thus, serum IL10 was entered as dependent variable. The independent covariates included anthropometry indices (\% body fat, BMI, waist circumference), blood glucose and lipid profile (SBP/DBP, total cholesterol, TG, HDL, LDL, fasting insulin, fasting glucose, HOMA-IR index), iron parameters (serum iron, serum TIBC, serum ferritin, transferrin saturation, hepcidin) and pro-inflammatory cytokines (IL1 $\beta$, TNF $\alpha$, IFN $\gamma, \mathrm{NO}$ ). The initial linear regression analysis showed no correlation between IL10 concentration and anthropometry indices, fasting blood glucose, and lipid profiles. Therefore, only iron parameters (serum iron, serum TIBC, serum ferritin, transferrin saturation, hepcidin) and pro-inflammatory cytokines (IL1 $\beta$, TNF $\alpha$, IFN $\gamma$, $\mathrm{NO})$ were selected for multivariate analyses.

IL1 $\beta$ was independently associated with IL10 $(\beta=-0.157$, $\mathrm{p}<0.0001$ ), after adjusting for gender, serum TIBC, transferrin saturation, NO, TNF $\alpha$, IFN $\gamma$ and NO (Table 4; pooled, Multivariate model: B). When overweight/obese adolescents were assessed separately from normal weight, only IL1 $\beta$ was inversely associated with serum IL10 $(\beta=-0.231$, $\mathrm{p}=0.0009$ ) (Table 4; overweight and obese, Model D). The association between IL10 and IL1 $\beta$ became weaker in adolescents with normal weight ( $\beta=-0.157, p=0.0002)$, after further controlling for gender, NO, TNF $\alpha$, IFN $\gamma$ and $\mathrm{NO}$ (Table 4; pooled, Multivariate model: $\mathrm{C}$ ). The relationship between IL10 and IL1 $\beta$ appears to differ in the normal 
Table 2 Clinical and biochemical characteristics of children according to nutritional status

\begin{tabular}{|c|c|c|c|c|c|c|c|}
\hline & & & Ove & & & & Ordinary \\
\hline & Medium & IQR & Medium & IQR & Medium & IQR & P-trend \\
\hline Number (boys/girls) & 231 & & & & & & \\
\hline Height $^{\alpha}(\mathrm{cm})$ & 155.51 & 7.33 & 156.62 & 6.84 & $159.64^{\# \#}$ & 6.55 & 0.0002 \\
\hline Weight $^{a}(\mathrm{~kg})$ & 44.67 & 6.68 & $57.38^{* *}$ & 5.32 & $70.80^{\# \#}$ & 9.59 & $<0.0001$ \\
\hline Waist $^{\text {a }}(\mathrm{cm})$ & 64.96 & 6.20 & $78.60^{* *}$ & 5.87 & $87.07^{\# \#}$ & 9.56 & $<0.0001$ \\
\hline Body fat $^{\text {a }}(\%)$ & 18.57 & 5.56 & $26.51^{* *}$ & 4.52 & $32.10^{\# \#}$ & 7.45 & $<0.0001$ \\
\hline Fasting glucose (mg/dL) & 90.00 & 8.00 & 91.50 & 8.50 & $92.00^{\#}$ & 11.00 & 0.0005 \\
\hline Fasting serum insulin & 11.37 & 5.96 & $16.20^{* *}$ & 6.19 & $28.44^{\# \#}$ & 19.68 & $<0.0001$ \\
\hline HOMA-IR & 2.58 & 1.40 & $3.63^{* *}$ & 1.50 & $6.50^{\# \#}$ & 4.58 & $<0.0001$ \\
\hline SBP $(\mathrm{mmHg})$ & 109.00 & 12.00 & 111.50 & 15.50 & $116.00^{\# \#}$ & 11.00 & $<0.0001$ \\
\hline $\mathrm{DBP}(\mathrm{mmHg})$ & 62.00 & 11.00 & 61.00 & 10.00 & $66.00^{\# \#}$ & 8.00 & 0.0065 \\
\hline HDL- cholesterol (mg/dL) & 58.00 & 17.00 & $49.00^{* *}$ & 14.00 & $42.50^{\# \#}$ & 13.00 & $<0.0001$ \\
\hline LDL- cholesterol (mg/dL) & 88.00 & 29.00 & 92.50 & 36.50 & 88.50 & 24.00 & 0.6458 \\
\hline Total cholesterol (mg/dL) & 158.00 & 37.00 & 160.50 & 47.00 & 151.00 & 33.00 & 0.1283 \\
\hline Triglyceride (mg/dL) & 62.00 & 32.00 & 68.00 & 44.00 & $78.00^{\# \#}$ & 51.00 & $<0.0001$ \\
\hline Serum iron (ug/dL) & 86.00 & 45.00 & 87.50 & 39.00 & 80.00 & 38.00 & 0.3875 \\
\hline Serum TIBC (ug/dL) & 342.00 & 58.00 & 359.00 & 61.00 & 343.00 & 59.00 & 0.6752 \\
\hline Serum ferritin (ng/dL) & 50.00 & 42.00 & 40.00 & 42.50 & 47.00 & 34.00 & 0.4136 \\
\hline Transferritin Saturation (\%) & 24.90 & 14.18 & 25.32 & 15.65 & 22.89 & 11.51 & 0.5224 \\
\hline Hepcidin (ng/ml) & 123.19 & 22.02 & 107.26 & 25.80 & $120.07^{\#}$ & 34.35 & 0.0062 \\
\hline TNFa (pg/ml) & 16.69 & 10.37 & $21.42^{*}$ & 12.30 & 21.56 & 11.44 & 0.1982 \\
\hline IFNy (pg/ml) & 5.92 & 3.10 & 6.41 & 2.48 & 6.16 & 3.38 & 0.8630 \\
\hline IL10 (pg/ml) & 9.87 & 3.69 & $8.13^{*}$ & 2.74 & 9.08 & 3.41 & 0.5265 \\
\hline IL1 $\beta(p g / m l)$ & 0.90 & 0.41 & $1.15^{*}$ & 0.62 & $1.11^{\# \#}$ & 0.75 & 0.0006 \\
\hline NO (uM) & 6.13 & 5.74 & $9.54^{* *}$ & 5.97 & 8.05 & 4.29 & 0.0606 \\
\hline
\end{tabular}

Data are presented as median \pm interquartile range (IQR).

" presented as mean \pm standard error of mean (SEM).

$\#,{ }^{*} p<0.05$. Statistically different versus normal weight children by t-test.

$\# \#, \quad$,** $<0.01$. Statistically different versus normal weight children by t-test.

weight and overweight/obese children. All students were from the first year junior high school, so there was very little variation in age. The correlation between IL10 and IL1 $\beta$ was similar between girls and boys $\left(R^{2}=0.110\right.$ v.s. $\left.R^{2}=0.0908\right)$ and between overweight/obese and normal weight $\left(R^{2}=0.113\right.$ v.s. $\left.R^{2}=0.0912\right)$. However, the correlation between IL10 and IL1 $\beta$ in normal weight girls differed from those of overweight/obese girls $\left(R^{2}=0.0858\right.$ v.s. $R^{2}=0.212$; respectively) and between normal weight and overweight/ obese boys $\left(R^{2}=0.0903\right.$ v.s. $R^{2}=0.0492$; respectively) (Figure 1). These data indicate that IL1 $\beta$ is independently correlated with IL10 homeostasis and this association is more pronounced in girls who are overweight or obese.

\section{Discussion}

In the present study, we confirmed that young adolescents who are overweight and obese had decreased circulating IL10 concentration and increased proinflammatory cytokines TNF $\alpha$, IL1 $\beta$ and NO. Our study also found that pro-inflammatory cytokine IL1 $\beta$ and IL10 are independently associated. A decline in serum IL10 concentration in overweight and obese adolescents may further contribute to the IL1 $\beta$-mediated inflammatory environment associated with obesity. IL1 $\beta$ has been associated with the destruction of the insulin-producing beta cell [28]. Administration of neutralizing monoclonal antibodies to IL1 $\beta$ improved glycemic control and beta cell function in type 2 diabetic patients [29]. Our study showed IL10 concentration was neither correlated with blood glucose homeostasis variables nor blood lipid profiles. This is partially explained by the low prevalence rate of MetS in the study subjects. IL10 plays a critical role in limiting inflammation and a switch in anti- and pro-inflammatory balance towards pro-inflammatory state in overweight and obese adolescents may promote the progression of normal glucose tolerance to insulin resistance in adulthood [30]. The pathogenesis of type 2 diabetes is complex, involving the interaction of genetic 
Table 3 Pearson's rank correlation coefficient and partial $r$ of log-transformed serum IL10 with selected anthropometric, iron status, individual components of MetS and inflammatory indicators analyzed in all subjects $(n=325)$

\begin{tabular}{|c|c|c|c|c|}
\hline & \multicolumn{2}{|c|}{ Model $1^{a}$} & \multicolumn{2}{|c|}{ Model $2^{b}$} \\
\hline & $r$ & $p$ value & $r$ & $p$ value \\
\hline Gender & -0.03064 & 0.5821 & & \\
\hline Log Body fat (\%) & 0.04426 & 0.4265 & 0.0396 & 0.4775 \\
\hline Log BMI(kg/m²) & -0.06153 & 0.2687 & -0.06149 & 0.2697 \\
\hline Log waist(cm) & 0.08005 & 0.1499 & 0.08226 & 0.1396 \\
\hline Log Sytolic BP(mmHg) & -0.00615 & 0.9125 & -0.00621 & 0.9113 \\
\hline Log Diastolic BP(mmHg) & 0.03219 & 0.5631 & 0.02999 & 0.5906 \\
\hline Log Total cholesterol(mg/dL) & -0.05163 & 0.3535 & -0.05337 & 0.3383 \\
\hline Log Triglyceride(mg/dL) & -0.04992 & 0.3697 & -0.05166 & 0.3540 \\
\hline Log HDL cholesterol (mg/dL) & 0.04768 & 0.3915 & 0.04941 & 0.9285 \\
\hline Log LDL- cholesterol (mg/dL) & -0.00157 & 0.9775 & -0.00501 & 0.9285 \\
\hline Log Fasting serum insulin $(\mu \mathrm{lU} / \mathrm{ml})$ & 0.02903 & 0.6021 & 0.02846 & 0.6097 \\
\hline Log Fasting glucose (mg/dL) & 0.04581 & 0.4105 & 0.04758 & 0.3933 \\
\hline HOMA-IR & 0.03339 & 0.5487 & 0.03309 & 0.5528 \\
\hline Log Serum iron(ug/dL) & 0.09526 & 0.0864 & 0.0955 & 0.0861 \\
\hline Log Serum TIBC(ug/dL) & -0.13754 & 0.0131 & -0.13789 & 0.0130 \\
\hline Log Serum ferritin(ng/ml) & -0.02723 & 0.3535 & -0.02548 & 0.6477 \\
\hline Log Transferrin Saturation & 0.13037 & 0.0131 & 0.1307 & 0.0186 \\
\hline Log Hepcidin (ng/ml) & 0.26157 & $<0.0001$ & 0.27054 & $<0.0001$ \\
\hline $\log \operatorname{IL} 1 \beta(p g / m l)$ & -0.32945 & $<0.0001$ & -0.32826 & $<0.0001$ \\
\hline Log TNFa (pg/ml) & -0.21078 & 0.0001 & -0.20954 & 0.0001 \\
\hline Log IFNy(pg/ml) & -0.14038 & 0.0113 & -0.13892 & 0.0123 \\
\hline $\log N O(\mu \mathrm{M})$ & -0.285 & $<0.0001$ & -0.28661 & $<0.0001$ \\
\hline Log GOT (IU/L) & 0.03548 & 0.5239 & 0.04253 & 0.4455 \\
\hline Log GPT (IU/L) & -0.09192 & 0.0981 & -0.08804 & 0.1137 \\
\hline
\end{tabular}

a Model1: Crude.

${ }^{\mathrm{b}}$ Model2: Adjusted for gender.

and environmental risk factors. Therefore, a longitudinal follow up study on obese children and adolescents is needed to clarify the role of IL10 in the progression of type 2 diabetes and MetS.

The association between IL10 and IL1 $\beta$ was more pronounced in girls who are overweight or obese. Both overweight/obese boys and girls had elevated serum IL1 $\beta$ concentrations. However, correlations between IL10 and IL1 $\beta$ concentrations were greater in overweight/obese girls $\left(R^{2}=0.212\right)$ than boys $\left(R^{2}=0.049\right)$. Corcoran et al. investigated the effect of estrogen and testosterone on the expression of pro-inflammatory mediators in macrophages obtained from patients with coronary heart disease [31]. The authors showed testosterone reduced the expression of TNF $\alpha$ and IL1 $\beta$; by contrast, estrogen did not have these adverse effects [31]. In our study, serum IL1 $\beta$ concentrations were similarly increased in both overweight/obese boys and girls.
This suggests that the difference between the two groups is less likely to be explained by the effect of sex hormones on IL1 $\beta$. Adipose tissues derived adiponectin is a potential mediator of IL10 [32]. Adiponectin concentrations are inversely correlated with waist circumference, BMI and total body fat [33]. We found that overweight/ obese boys had slightly higher waist circumference than overweight/obese girls $(84.7 \pm 3.2 \mathrm{~cm}$ v.s. $81.1 \pm 2.7 \mathrm{~cm}$; $\mathrm{p}=0.06$ ). Although it did not reach statistical significance, overweight/obese boys had slightly lower IL10 concentrations when compared with overweight/obese girls. This contributed to a lower ratio of IL10/ IL1 $\beta$ in overweight/obese boys than girls $(8.77 \pm 0.65$ v.s. $9.93 \pm 0.86$; $\mathrm{p}=0.35$ ). We hypothesize that adiponectin concentrations may contribute to the gender difference in IL10 and IL1 $\beta$ association in overweight/obese adolescents.

Interleukins (ILs) are key mediators of the innate immune response and inflammatory process. So far, 11 
Table 4 Linear regression analyses of predictors of serum IL10 in young adolescents

\begin{tabular}{|c|c|c|c|c|c|c|}
\hline \multirow[b]{2}{*}{ Pooled $(n=325)$} & \multicolumn{2}{|c|}{ Crude } & \multicolumn{2}{|c|}{ Model $A^{*}$} & \multicolumn{2}{|c|}{ Multivariate model $(B)^{\#}$} \\
\hline & $\beta$ & p-value & $\beta$ & p-value & $\beta$ & $p$-value \\
\hline Log Serum iron(ug/dL) & 0.06702 & 0.0864 & 0.06716 & 0.0861 & & \\
\hline Log Serum TIBC(ug/dL) & -0.30981 & 0.0131 & -0.31047 & 0.013 & -0.1578 & 0.2026 \\
\hline Log Serum ferritin(ng/ml) & -0.01122 & 0.6248 & -0.01051 & 0.6477 & & \\
\hline Log Transferrin Saturation (\%) & 0.08652 & 0.0187 & 0.08670 & 0.0186 & 0.04459 & 0.21111 \\
\hline Log Hepcidin (ng/ml) & -0.1275 & 0.0478 & -0.13164 & 0.0502 & & \\
\hline $\log \operatorname{IL1} \beta(p g / m l)$ & -0.21868 & $<0.0001$ & -0.21834 & $<0.0001$ & -0.1568 & $<0.0001$ \\
\hline Log TNF (pg/ml) & -0.15167 & 0.0001 & -0.15092 & 0.0001 & -0.08206 & 0.0317 \\
\hline Log IFNy (pg/ml) & -0.12521 & 0.0113 & -0.12405 & 0.0123 & -0.11378 & 0.0124 \\
\hline $\log N O(\mu M)$ & -0.12417 & $<0.0001$ & -0.12491 & $<0.0001$ & -0.08628 & 0.0002 \\
\hline \multirow[t]{2}{*}{ Normal weight $(n=231)$} & \multicolumn{2}{|c|}{ Crude } & \multicolumn{2}{|c|}{ Model A* } & \multicolumn{2}{|c|}{ Multivariate model $(C) ※$} \\
\hline & $\beta$ & p-value & $\beta$ & $p$-value & $\beta$ & $p$-value \\
\hline Log Serum iron(ug/dL) & 0.05598 & 0.2483 & 0.05604 & 0.2487 & & \\
\hline Log Serum TIBC(ug/dL) & -0.29762 & 0.0665 & -0.29704 & 0.0676 & & \\
\hline Log Serum ferritin(ng/ml) & -0.02808 & 0.3080 & -0.02826 & 0.3061 & & \\
\hline Log Transferrin Saturation (\%) & 0.07590 & 0.1022 & 0.07590 & 0.1029 & & \\
\hline Log Hepcidin (ng/ml) & -0.19145 & 0.3327 & -0.23717 & 0.2584 & & \\
\hline $\log \operatorname{IL1} \beta(p g / m l)$ & -0.20687 & $<0.0001$ & -0.20810 & $<0.0001$ & -0.1572 & 0.0002 \\
\hline Log TNF (pg/ml) & -0.16167 & 0.0007 & -0.16165 & 0.0008 & -0.0829 & 0.07 \\
\hline Log IFNy (pg/ml) & -0.13909 & 0.0178 & -0.13939 & 0.0178 & -0.10408 & 0.0548 \\
\hline $\log N O(\mu M)$ & -0.14744 & $<0.0001$ & -0.14735 & $<0.0001$ & -0.10764 & 0.0002 \\
\hline \multirow[t]{2}{*}{ Overweight and obese $(n=94)$} & \multicolumn{2}{|c|}{ Crude } & \multicolumn{2}{|c|}{ Model A* } & \multicolumn{2}{|c|}{ Model $\mathrm{D}^{\S}$} \\
\hline & $\beta$ & p-value & $\beta$ & p-value & $\beta$ & $p$-value \\
\hline Log Serum iron(ug/dL) & 0.08013 & 0.2147 & & & & \\
\hline Log Serum TIBC(ug/dL) & -0.31443 & 0.0932 & & & & \\
\hline Log Serum ferritin(ng/ml) & 0.03041 & 0.4575 & 0.04130 & 0.3155 & & \\
\hline Log Transferrin Saturation (\%) & 0.09707 & 0.0975 & 0.10025 & 0.0848 & & \\
\hline Log Hepcidin (ng/ml) & -0.08019 & 0.2256 & -0.06115 & 0.3845 & & \\
\hline $\log \mid \mathrm{L} 1 \beta(p g / m l)$ & -0.23952 & 0.0005 & -0.23111 & 0.0009 & -0.23111 & 0.0009 \\
\hline Log TNF (pg/ml) & -0.09581 & 0.1846 & -0.07848 & 0.2831 & & \\
\hline Log IFNy (pg/ml) & -0.07007 & 0.4424 & -0.04873 & 0.5962 & & \\
\hline $\log N O(\mu M)$ & -0.04679 & 0.2784 & -0.05602 & 0.1944 & & \\
\hline
\end{tabular}

${ }^{*}$ Model A: Adjusted for gender.

\#Model B: Multivariate model adding gender.

*Model C: Multivariate model adding gender.

${ }^{\S}$ Model D: Adjusted for gender.

members of the IL1 family have been identified including IL1 $\alpha$, IL1 $\beta$ and IL1 receptor antagonist (IL1Ra) [28]. Circulating IL1 $\beta$ and IL1Ra are elevated in patients with obesity and type 2 diabetes [34]. Short-term IL1 $\alpha$ treatment transiently causes insulin resistance at insulin receptor substrate 1 level in 3T3L1 adipocytes [35]. IL1Ra is regarded as anti-inflammatory cytokine but it does not directly elicit an anti-inflammatory response. It binds tightly to IL $1 \alpha$ and IL1 $\beta$ receptor on the cell surface, hence blocking the activity of either IL1 $\alpha$ or IL1 $\beta$. A recent report showed 13 weeks of IL1Ra therapy improved glycemic control and the function of the insulinproducing beta cell in patients with type 2 diabetes [34].

In this study, we also observed a positive relationship between IL10 and iron status. Associations between obesity and poor iron status have recently been described in White and Hispanic children [36,37]. However, we found no difference in iron status between normal body weight and overweight/obese adolescents (data not shown). The relationship between IL10 and iron metabolism is poorly understood. Patients with Crohn's disease receiving higher doses of IL10 developed 


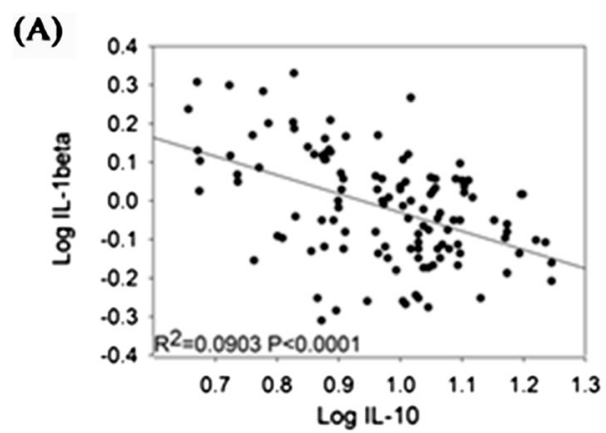

(C)

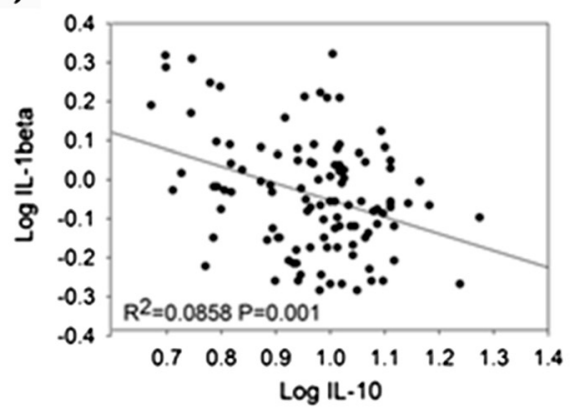

(B)

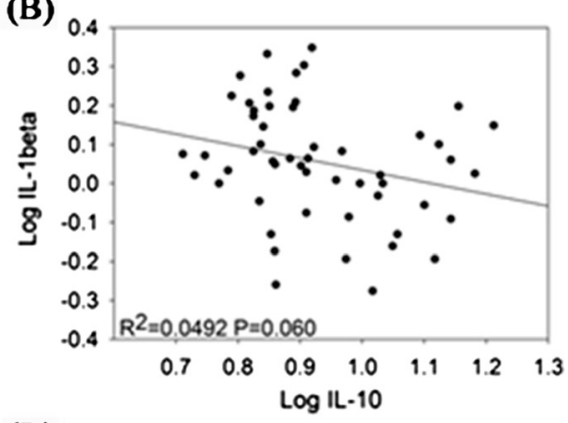

(D)

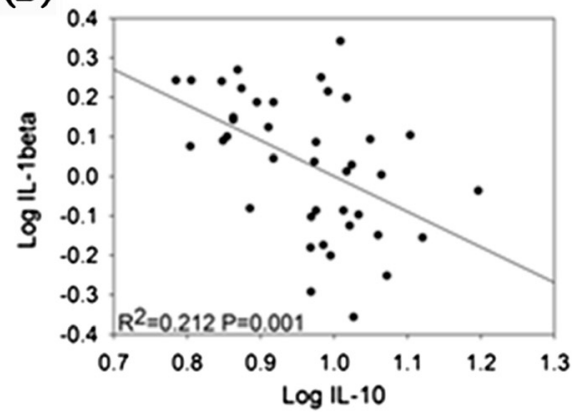

Figure 1 Correlation between IL10 and IL1 $\beta$ stratified by gender and BMI in 340 subjects (182 boys and 158 girls). Pearson's correlation coefficient correlation between IL10 and IL1 $\beta$ in normal weight boys (A), overweight/obese boys (B), normal weight girls (C) and (D) overweight/obese girls.

anemia and a dose-dependent increase of serum ferritin concentration [19]. The authors suggested that hyperferritinemia may result from direct stimulation of ferritin translation by IL10 via the suppression of the binding affinity of iron regulatory proteins to the 5'-untranslated region of ferritin mRNA in human monocytic cells [19]. Macrophages play a key role in the iron homeostasis. Through erythrophagocytosis of senescent red blood cells, macrophages recycle and redistribute heme iron to the plasma. Chau et al. showed IL10 triggers expression of heme oxygenase $1(\mathrm{HO}-1)$ via the $\mathrm{p} 38$ MAPK pathway and IL10-HO1 pathways are critical for the protection against LPS-induced septic shock in mice [38]. These data suggest that abnormal high concentration of IL10 may limit iron bioavailability to erythroid progenitor cells; whilst, defective IL10 production may impair $\mathrm{HO} 1$ mediated anti-inflammatory and antioxidant responses. Nevertheless, the consequences of defective IL10 synthesis and erythrogenesis in overweight and obese adolescents need to be further investigated in a longitudinal study.

There are several limitations in our study. The crosssectional nature of the current study and the relative small sample size are one of the limitations. Further, the inverse correlation between serum IL10 and proinflammatory cytokines may be casual and related to IL10 polymorphisms. IL-10 secretion is tightly controlled and under a stringent genetic regulation with
$75 \%$ of heritability [39]. The three polymorphisms $1082 \mathrm{G} / \mathrm{A},-819 \mathrm{C} / \mathrm{T}$, and $-592 \mathrm{C} / \mathrm{A}$ in the IL10 promoter region were reported to influence IL10 transcription. A promoter polymorphism $(-592 \mathrm{C} / \mathrm{A})$ was associated with lower circulating IL-10 levels and an increased risk for obesity and insulin resistance in Italian people [40]. However, this association was not confirmed in the Chinese population [41]. Another limitation is that we could not confirm which IL10-producing cells are affected in obese children.

\section{Conclusions}

In conclusion, given the increasing numbers of obese children in the population, it is critical to investigate the factors associated with the obesity-related declines in health. Our study confirmed that low IL10 concentration is associated with overweight and obesity in young adolescents. A decline in serum IL10 concentration in overweight and obese adolescents may further contribute to the IL1 $\beta$-mediated inflammatory environment associated with obesity.

\section{Abbreviations}

IL10: Interleukin 10; NO: Nitric oxide; MetS: Metabolic syndrome; SF: Serum ferritin; TS: Transferrin saturation; TIBC: Total iron binding capacity; BMI: Body mass index; LDL: Low density lipoprotein cholesterol; HDL: High density lipoprotein cholesterol; TG: Triglyceride; SEM: Standard error of mean; PBMC: Peripheral blood mononuclear cells; HO-1: Heme oxygenase 1; LPS: Lipopolysaccharide; FPG: Fasting plasma glucose concentration; IL1Ra: IL1 receptor antagonist. 


\section{Competing interests}

All authors declare that they have not received support (financial and nonfinancial) from any companies for the submitted work; no authors have any relationship with companies that may have an interest in the submitted work; their spouses, partners, or children.

\section{Authors' contributions}

JSC conceptualized and designed the study, drafted the initial manuscript, and approved the final manuscript CCC and EYC contributed to the study design, data acquisition and initial data analysis. SSL conducted preparation and examination of cytokines. CST carried out the iron biochemistry analysis and $\mathrm{CHB}$ supervised the data collection and statistical analysis. KCC critically reviewed the manuscript and approved the final manuscript. All authors read and approved the final manuscript.

\section{Acknowledgments}

We appreciate the participation of all the subjects in this study. We thank the staff from the Taipei Medical Hospital and University for their technical assistance. Dr. Jung-Su Chang was supported by grant 101TMU-TMUH-04.

\section{Author details}

${ }^{1}$ School of Nutrition and Health Sciences, College of Public Health and Nutrition, Taipei Medical University, Taipei, Taiwan R.O.C. ${ }^{2}$ Division of Gastroenterology and Hepatology, Department of Internal Medicine, Taipei Medical University Hospital, Taipei, Taiwan R.O.C. ${ }^{3}$ Department of Internal Medicine, School of Medicine, College of medicine, Taipei Medical University, 110, Taipei, Taiwan R.O.C. ${ }^{4}$ School of Public Health, Taipei Medical University, Taipei, Taiwan R.O.C. ${ }^{5}$ Department of Public Health, College of Medicine, Taipei Medical University, Taipei, Taiwan R.O.C.

Received: 24 January 2013 Accepted: 7 August 2013

Published: 14 August 2013

\section{References}

1. Rahim SS, Khan N, Boddupalli CS, Hasnain SE, Mukhopadhyay S: Interleukin10 (IL-10) mediated suppression of IL-12 production in RAW 264.7 cells also involves c-rel transcription factor. Immunology 2005, 114:313-321.

2. Vasu C, Gorla SR, Prabhakar BS, Holterman MJ: Targeted engagement of CTLA-4 prevents autoimmune thyroiditis. Int Immunol 2003, 15:641-654.

3. Couper KN, Blount DG, Riley EM: IL-10: the master regulator of immunity to infection. J Immunol 2008, 180:5771-5777.

4. Stoppa-Vaucher S, Dirlewanger MA, Meier CA, de Moerloose P, Reber G, Roux-Lombard P, Combescure C, Saudan S, Schwitzgebel VM: Inflammatory and prothrombotic states in obese children of European descent. Obesity (Silver Spring) 2012, 20:1662-1668.

5. Nishida M, Moriyama T, Sugita Y, Yamauchi-Takihara K: Interleukin-10 associates with adiponectin predominantly in subjects with metabolic syndrome. Circ J 2007, 71:1234-1238.

6. Bosutti A, Malaponte G, Zanetti M, Castellino P, Heer M, Guarnieri G, Biolo G: Calorie restriction modulates inactivity-induced changes in the inflammatory markers C-reactive protein and pentraxin-3. J Clin Endocrinol Metab 2008, 93:3226-3229.

7. Han X, Kitamoto S, Wang H, Boisvert WA: Interleukin-10 overexpression in macrophages suppresses atherosclerosis in hyperlipidemic mice. FASEB J 2010, 24:2869-2880.

8. Heeschen C, Dimmeler S, Hamm CW, Fichtlscherer S, Boersma E, Simoons ML, Zeiher AM: Serum level of the antiinflammatory cytokine interleukin10 is an important prognostic determinant in patients with acute coronary syndromes. Circulation 2003, 107:2109-2114.

9. Smith DA, Irving SD, Sheldon J, Cole D, Kaski JC: Serum levels of the antiinflammatory cytokine interleukin-10 are decreased in patients with unstable angina. Circulation 2001, 104:746-749.

10. Hong EG, Ko HJ, Cho YR, Kim HJ, Ma Z, Yu TY, Friedline RH, Kurt-Jones E, Finberg R, Fischer MA, et al: Interleukin-10 prevents diet-induced insulin resistance by attenuating macrophage and cytokine response in skeletal muscle. Diabetes 2009, 58:2525-2535.

11. Straczkowski M, Kowalska I, Nikolajuk A, Krukowska A, Gorska M: Plasma interleukin-10 concentration is positively related to insulin sensitivity in young healthy individuals. Diabetes Care 2005, 28:2036-2037.

12. van Exel E, Gussekloo J, de Craen AJ, Frolich M, Bootsma-Van Der Wiel A Westendorp RG: Low production capacity of interleukin-10 associates with the metabolic syndrome and type 2 diabetes : the Leiden 85-plus study. Diabetes 2002, 51:1088-1092.

13. Uyemura K, Demer LL, Castle SC, Jullien D, Berliner JA, Gately MK, Warrier RR, Pham N, Fogelman AM, Modlin RL: Cross-regulatory roles of interleukin (IL)-12 and IL-10 in atherosclerosis. The Journal of clinical investigation 1996, 97:2130-2138.

14. Forte GI, Pilato G, Vaccarino L, Sanacore M, Candore G, Romano GC, Testa R, Franceschi C, Capri M, Marra M, et al: Risk profiles in type 2 diabetes (metabolic syndrome): integration of IL-10 polymorphisms and laboratory parameters to identify vascular damages related complications. Curr Pharm Des 2010, 16:898-903.

15. Arslan N, Erdur B, Aydin A: Hormones and cytokines in childhood obesity. Indian Pediatr 2010, 47:829-839.

16. Calcaterra V, De Amici M, Klersy C, Torre C, Brizzi V, Scaglia F, Albanesi M, Albertini R, Allais B, Larizza D: Adiponectin, IL-10 and metabolic syndrome in obese children and adolescents. Acta Biomed 2009, 80:117-123

17. Gozal D, Serpero LD, Sans Capdevila O, Kheirandish-Gozal L: Systemic inflammation in non-obese children with obstructive sleep apnea. Sleep Med 2008, 9:254-259.

18. Tam CS, Garnett SP, Cowell CT, Heilbronn LK, Lee JW, Wong M, Baur LA: IL$6, \mathrm{IL}-8$ and IL-10 levels in healthy weight and overweight children. Horm Res Paediatr 2010, 73:128-134.

19. Tilg H, Ulmer H, Kaser A, Weiss G: Role of IL-10 for induction of anemia during inflammation. J Immunol 2002, 169:2204-2209.

20. Oldenburg B, van Berge Henegouwen GP, Rennick D, Van Asbeck BS Koningsberger JC: Iron supplementation affects the production of pro-inflammatory cytokines in IL-10 deficient mice. Eur J Clin Invest 2000, 30:505-510

21. Choy C, Huang Y, Liu Y, Yang C, Liao C, Li JS, Chiu W, Vhiou H: Waist circumference as a predictor of pediatric hypertension AAmong normal-weight Taiwanese children. J Exp Clin Med 2011, 3:34-39.

22. Pan WH, Lee MS, Chuang SY, Lin YC, Fu ML: Obesity pandemic, correlated factors and guidelines to define, screen and manage obesity in Taiwan. Obes Rev 2008, 9(Suppl 1):22-31.

23. Expert Panel on Detection, Evaluation, and Treatment of High Blood Cholesterol in Adults: Exceutive summary of the third report of the national cholesterol education program (NCEP) (adult treatment panel III). JAMA 2001, 285:2486-2497.

24. Tan CE, Ma S, Wai D, Chew SK, Tai ES: Can we apply the national cholesterol education program adult treatment panel definition of the metabolic syndrome to Asians? Diabetes Care 2004, 27:1182-1186.

25. Zimmet P, Alberti KG, Kaufman F, Tajima N, Silink M, Arslanian S, Wong G, Bennett $P$, Shaw J, Caprio S: The metabolic syndrome in children and adolescents - an IDF consensus report. Pediatric diabetes 2007, 8:299-306

26. Chu NF, Pan WH: Prevalence of obesity and its comorbidities among schoolchildren in Taiwan. Asia Pac J Clin Nutr 2007, 16(Suppl 2):601-607.

27. Wang JL, Shaw NS: Iron status of the Taiwanese elderly: the prevalence of iron deficiency and elevated iron stores. Asia Pac J Clin Nutr 2005, $14: 278-284$.

28. Dinarello CA: Immunological and inflammatory functions of the interleukin-1 family. Annu Rev Immunol 2009, 27:519-550.

29. Donath MY, Mandrup-Poulsen T: The use of interleukin-1-receptor antagonists in the treatment of diabetes mellitus. Nat Clin Pract Endocrinol Metab 2008, 4:240-241.

30. D'Adamo E, Caprio S: Type 2 diabetes in youth: epidemiology and pathophysiology. Diabetes Care 2011, 34(Suppl 2):S161-S165.

31. Corcoran MP, Meydani M, Lichtenstein AH, Schaefer EJ, Dillard A, Lamon-Fava S: Sex hormone modulation of proinflammatory cytokine and C-reactive protein expression in macrophages from older men and postmenopausal women. J Endocrinol 2010, 206:217-224

32. Kumada M, Kihara S, Ouchi N, Kobayashi H, Okamoto Y, Ohashi K Maeda K, Nagaretani H, Kishida K, Maeda N, et al: Adiponectin specifically increased tissue inhibitor of metalloproteinase-1 through interleukin-10 expression in human macrophages. Circulation 2004 109:2046-2049.

33. Milewicz A, Jedrzejuk D, Dunajska K, Lwow F: Waist circumference and serum adiponectin levels in obese and non-obese postmenopausal women. Maturitas 2010, 65:272-275. 
34. Larsen CM, Faulenbach M, Vaag A, Volund A, Ehses JA, Seifert B, MandrupPoulsen T, Donath MY: Interleukin-1-receptor antagonist in type 2 diabetes mellitus. N Engl J Med 2007, 356:1517-1526.

35. He J, Usui I, Ishizuka K, Kanatani Y, Hiratani K, Iwata M, Bukhari A, Haruta T, Sasaoka T, Kobayashi M: Interleukin-1alpha inhibits insulin signaling with phosphorylating insulin receptor substrate-1 on serine residues in 3T3L1 adipocytes. Mol Endocrinol 2006, 20:114-124.

36. del Giudice EM, Santoro N, Amato A, Brienza C, Calabro P, Wiegerinck ET, Cirillo G, Tartaglione N, Grandone A, Swinkels DW, Perrone L: Hepcidin in obese children as a potential mediator of the association between obesity and iron deficiency. J Clin Endocrinol Metab 2009, 94:5102-5107.

37. Nead KG, Halterman JS, Kaczorowski JM, Auinger P, Weitzman M: Overweight children and adolescents: a risk group for iron deficiency. Pediatrics 2004, 114:104-108.

38. Lee TS, Chau LY: Heme oxygenase-1 mediates the anti-inflammatory effect of interleukin-10 in mice. Nat Med 2002, 8:240-246.

39. Westendorp RG, Langermans JA, Huizinga TW, Verweij CL, Sturk A: Genetic influence on cytokine production in meningococcal disease. Lancet 1997, 349:1912-1913.

40. Scarpelli D, Cardellini M, Andreozzi F, Laratta E, Hribal ML, Marini MA, Tassi V, Lauro R, Perticone F, Sesti G: Variants of the interleukin-10 promoter gene are associated with obesity and insulin resistance but not type 2 diabetes in caucasian Italian subjects. Diabetes 2006, 55:1529-1533.

41. Hsueh KC, Lin YJ, Chang JS, Wan L, Tsai YH, Tsai CH, Chen CP, Tsai FJ: Association of interleukin-10 a-592C polymorphism in Taiwanese children with kawasaki disease. J Korean Med Sci 2009, 24:438-442.

doi:10.1186/1471-2431-13-123

Cite this article as: Chang et al:: Association between interleukin $1 \beta$ and interleukin 10 concentrations: a cross-sectional study in young adolescents in Taiwan. BMC Pediatrics 2013 13:123.

\section{Submit your next manuscript to BioMed Central and take full advantage of:}

- Convenient online submission

- Thorough peer review

- No space constraints or color figure charges

- Immediate publication on acceptance

- Inclusion in PubMed, CAS, Scopus and Google Scholar

- Research which is freely available for redistribution

Submit your manuscript at www.biomedcentral.com/submit
C Biomed Central 